\title{
How Fundamental are Fundamental Values? \\ Valuation Methods and Their Impact on the \\ Performance of German Venture Capitalists ${ }^{\dagger}$
}

\author{
Ingolf Dittmann \\ Ernst Maug ${ }^{\ddagger}$ \\ Johannes Kemper
}

This draft: November 15, 2002

\begin{abstract}
This paper studies how the use of alternative valuation methodologies affects investment performance for a sample of 53 German venture capitalists. We measure investment performance by the amount of investments they need to write off and by the number of companies they take public. We find that a significant number of investment managers use discounted cash flow (DCF) techniques, but only a minority appears to use a discount rate related to the cost of capital. The majority applies DCF using subjective discount rates. We present evidence that the use of DCF is correlated with superior investment performance only if applied in conjunction with an objectifiable discount rate. Also, funds that invest with a longer horizon perform better. The use of multiples is not significantly correlated with investment performance. We conclude that a focus on fundamental values confers an advantage.
\end{abstract}

Keywords: DCF, Performance, Valuation, Venture Capital, IPO

JEL Classification: G15, G24, G31

\footnotetext{
$\dagger$ We thank Thomas Hall, Christoph Kaserer, participants of the 2002 FMA European Conference, the 2002 conference of the German Finance Association, the quantitative finance seminar at Humboldt University, and in particular an anonymous referee for valuable comments on an earlier draft of this paper. We are grateful to the German Venture Capital Association (Bundesverband Deutscher Kapitalgesellschaften, BVK) for providing us with data on their member firms.

* School of Business and Economics, Institut für Konzernmanagement, Spandauer Str. 1, D-10178 Berlin, Germany. e-mail: maug@wiwi.hu-berlin.de, dittmann@wiwi.hu-berlin.de.
} 


\section{Introduction}

In this paper we address the question of how venture capital funds in Germany value their investments and how the use of alternative valuation techniques affects investment performance. We use data on 53 German venture capital funds who engage in early stage financing. We describe the valuation methods they use and present some evidence that the likelihood of success increases if the investment strategy is based on fundamental values or if it is oriented towards the long term.

Venture capital in Germany is a young industry that emerged only in the middle of the 1990 s as a recognizable source of finance when it emancipated itself from its traditional ties to major German commercial banks. ${ }^{1}$ This process coincided with the emergence of the "Neuer Markt," a new segment for young companies at the German Stock Exchange that was formally founded in March 1997. Subsequently, the average number of German initial public offerings surged from merely 16 per year between 1980 and 1996 to 132 per year between 1998 and 2000. The market peaked in March 2000 and steeply declined during 2000 and 2001. By September 2001 it had lost over $85 \%$ of its peak value. A significant number of venture capital funds had to write-off their investments, and many of the companies they took public in recent years now list below their issue price. ${ }^{2}$ These developments raised eyebrows and led to concerns about the expertise of venture capitalists and market analysts when valuing young start-ups, particularly technology companies. For this reason we ask two questions in this paper. First, we wish to know how German venture capitalists value companies in their portfolio. Here we limit our attention to those venture capitalists who engage in early stage financing of young technology start-ups. We investigate which methodologies they use, and, more importantly, how they implement them. We want to know to what extent the practice of venture capitalists in Germany conforms to the prescriptions of conventional finance textbooks.

\footnotetext{
${ }^{1}$ See Leopold and Frommann (1998), Schefczyk (2000) and Stummer and Nolte (2000) for a more detailed history of German venture capital.

${ }^{2}$ One consequence was that the German Stock Exchange recently tried to amend the rules regulating the listing of penny stocks. This would allow the stock exchange to delist stocks that have traded below $1 €$ for a certain period of time. Recently the German Stock Exchange announced plans to close the Neuer Markt altogether.
} 
Second, we wish to know how variations in valuation methodologies affect the investment performance of venture capital companies. Short of direct data on investment performance we measure success in two ways. We look at the porportion of investments that need to be written off, and at the number of companies that they take public. Effectively, we ask if the extent to which venture capitalists apply standard textbook procedures is linked to their likelihood of avoiding companies that fail, respectively, that succeed.

We collected data from 53 German venture capital companies engaged in early stage financing. Most of them use several methods in order to value companies they wish to invest in, three different methods on average. Discounted cash flow analysis - the main method conventionally taught in finance textbooks - is used by $58 \%$ of our respondents. However, detailed questions about the implementation of DCF analysis reveals that only about one third of DCF users choose the textbook approach for determining the discount rate. The majority of DCF users applies subjective ad hoc adjustments. We suspect that many respondents pay lip service to the use of discounted cash flow techniques because they know about its importance in business school teaching, yet feel uncomfortable with its methodological constraints. Interestingly, we find that those companies who say they use discounted cash flow analysis do not perform better as measured by the average write-off rate compared to those companies that do not claim to use discounted cash flow analysis. However, companies that use DCF and provide some evidence that they subject themselves to the methodological constraints imposed by DCF outperform those companies that either do not use DCF at all or use it with significant subjective adjustments, particularly to the discount rate: venture capitalists that use DCF and determine the discount rate according to standard textbook recommendations experience a write-off rate that is lower by 5.4 percentage points.

The write-off rate is not correlated with any of the size variables in our dataset. We suspected that those venture capital funds that invest in smaller and riskier companies also display a higher failure rate. However, we find no confirmation for this in our data. We also find no evidence for a lower write-off rate of larger funds, which we suspected have more resources to invest in specialist valuation expertise. However, we find that the investment attitude reflected in the length of the investment horizon is 
significantly related to investment success. Venture capitalists who have a longer time horizon also experience fewer failures. We interpret our results as saying that venture capitalists who have a stronger focus on fundamental values, so that they rely on rigorous discounted cash flow analysis and then take a long-term view on their portfolio investments, are on average more successful.

We also construct and analyse two measures of performance based on the number of IPOs a venture capitalist backed and on the revenues generated by such IPOs. The advantage of these measures compared to the write-off rate is that they are not selfreported. However, it turns out that only a minority of the venture capitalists in our sample (14 out of 53) actually did support IPOs. The picture that emerges from our data on 57 IPOs is that small venture capitalists sell their investments to larger venture capitalists one or two years before the IPO. This specialization on IPOs by a few venture capitalists clearly reduces the informativeness of these measures. We obtain no significant correlations between the venture capitalists' valuation practice and their IPO success, although signs are typically as expected.

The remaining part of this paper is organized as follows. In Section 2 we discuss the related literature. Section 3 provides some background on venture capital in Germany. In Section 4 we explain our research methodology and the construction of our questionnaire. Section 5 presents our findings on alternative valuation methodologies used by venture capitalists in Germany. This section also presents two sample evaluations in more detail. In Section 6 we relate the usage of valuation procedures to investment performance. Finally, Section 7 concludes.

\section{Discussion of the Literature}

Company valuation is a major component of modern finance theory and teaching. Standard finance textbooks such as Brealey and Myers (2000) and Ross, Westerfield and Jaffe (2001) typically recommend discounted cash flow analysis (DCF) and sometimes consider the internal rate of return method (IRR). More comprehensive overviews of commonly used methods are Cornell (1993) and Damodaran (2001), who also include valuation methods based on book values, comparable companies, and real options. In addition, Damodaran (2001) points out the pitfalls of the individual methods if they are applied to young technology firms. Other monographs 
like Copeland, Koller and Murrin (1990), Benninga and Sarig (1997), Palepu, Bernard and Healy (2000), or Drukarczyk (2001) deal with net present-value methods in more detail.

A fair number of surveys address the question which valuation methods are actually used in practice. Most of these papers concentrate on large firms and the methods they use for the allocation of capital among competing projects. The most comprehensive survey is Graham and Harvey (2001). ${ }^{3}$ They evaluate the answers of 392 chief financial officers (CFOs) of a broad variety of U.S. companies and find that, compared to earlier research, net present value (NPV) methods have become more popular over time. $74.9 \%$ of their respondents stated that they always or almost always use net present value techniques. Most interestingly, CFOs of larger firms were more likely to employ net present value methods than CFOs of smaller firms. Other popular methods were IRR, hurdle rates and payback. Manigart et al (1997, 2000) describe and compare valuation methods used by venture capitalists in five countries (US, UK, France, the Netherlands and Belgium). Our results complement their research by providing comparable information on German venture capitalists. While these surveys provide a good description of valuation methods used in practice, they remain silent about the usefulness of these methods: We are not aware of any paper that connects the use of a particular valuation method with a measure of company performance.

Another strand of the literature uses different valuation measures to forecast the market price of a given company. This literature can potentially identify successful methods, but it is uncertain whether these methods are actually applied in this particular way in practice. Most papers of this literature compare several variants of the multiple (comparable company) method (see, e.g., Boatsman and Baskin, 1981, Alford, 1992, and Kim and Ritter, 1999) because the necessary data are easily available. Discounted cash-flow methods, however, rely on cash-flow forecasts which are not available in general, so that only few studies exist. Kaplan and Ruback (1995) compare DCF with multiples for highly leveraged transactions and Gilson, Hotchkiss

\footnotetext{
${ }^{3}$ Other surveys are Bruner, Eades, Harris and Higgins (1998), Epps and Mitchem (1994), Gitman and Mercurio (1982), Moore and Reichert (1983), Sangster (1993), Shao and Shao (1996) and Stanley and Block (1984).
} 
and Ruback (2000) perform a similar analysis for firms emerging from bankruptcy. Both studies find that DCF slightly dominates multiples.

Apart from the valuation literature, there exists a sizable theoretical and empirical literature on venture capital. Gompers and Lerner (1999) provide an excellent overview. The main themes of this literature are the optimal organization of venture capital firms and the optimal venture capital contracts in order to overcome incentive problems and informational problems between venture capital provider and receiver. Other topics include the money flowing into and out of venture capital funds and the timing of IPOs or other exit choices. Empirical evidence on the success of venture capital firms has been provided by Brav and Gompers (1997) and Gompers and Lerner (1998). Brav and Gompers (1997) show that venture-backed IPOs outperform non-venture backed IPOs over a five-year period. Gompers and Lerner (1998) analyse the influence of different organizational structures of venture capital firms on the success of these firms. We follow their approach by proxying success by the probability that the firms which receive venture capital financing go public and by the probability that they go bankrupt. To our knowledge, the present paper is the first to describe the valuation methods used by German venture capitalists and, more generally, to analyze the link between their choice of valuation methods and their investment performance.

\section{Venture Capital in Germany}

Venture capital, which has a long tradition in the Anglo-American countries, is a relatively recent phenomenon in Germany. Traditionally, start-up companies were financed either without outside finance or through conventional bank loans. A traditional source of capital for small and medium-sized companies after World War II was the KfW (Kreditanstalt für Wiederaufbau) that emerged from the European Recovery Program (Marshall-Plan). The start-up phase of venture capital dates back to the period from 1965 to 1972 when 32 new Equity Participation Funds ("Kapitalbeteiligungsgesellschaften") were founded. However, these companies invested mostly in established small to medium-sized businesses and do not qualify as venture capitalists in the narrow sense of the word. 
A change in the regulatory environment in 1970 subsidised venture capitalists for making investments in the early stage of a company. ${ }^{4}$ This led to more investments in young companies. After a temporary collapse due to the oil price shock, the German venture capital industry recovered in the late 1970s. In 1989, the BVK (Bundesverband Deutscher Kapitalbeteiligungsgesellschaften, German Venture Capital Association) was founded. However, relative to the size of the economy, venture capital remained unimportant in Germany well into the middle of the 1990s. Until then, most German venture capital companies were subsidiaries of established banks. The creation of the "Neuer Markt" in 1997 then provided a new exit for venture capitalists and the industry started to attract entrants, particularly institutional investors, which were independent of traditional banks. German venture capitalists, like their counterparts in other countries, began investing in internet companies, telecommunications, and 'new' media. The gross investment volume of all BVK registered venture capitalists increased from $€ 481 \mathrm{~m}$ in 1990 to $€ 611 \mathrm{~m}$ in 1996 and then quickly accelerated to $€ 2,816 \mathrm{~m}$ in 1999 . Since the beginning of the 1990 s the BVK covers about $80 \%$ of the venture capital market in Germany and we can make reliable inferences from their membership on the German venture capital market as a whole.

During the 1990s the nominal amount of capital managed by each venture capital professional also doubled from an average of $€ 7.4 \mathrm{~m}$ per professional in 1990 to $€ 15.6 \mathrm{~m}$ per professional in 1999. Simultaneously with a shift from venture capital companies that were subsidiaries of the major banks to independent venture capitalists and alongside the enormous growth during the 1990s, we can also observe a shift in the structure of venture capital financing.

Insert Table 1 about here

We can see from Table 1 that investments in the expansion of mature companies contributed about two thirds of all venture capital investments in Germany in 1990. The same item amounted to little more than one third in 1999. Also the buyout-

\footnotetext{
${ }^{4}$ They could refinance $75 \%$ of their equity participations in their portfolio companies at the KfW for a subsidised interest rate. In addition they could cover $70 \%$ of the risk of loss through guarantees underwritten by the state governments or the federal government.
} 
market, contributing more than a fifth in 1990, was reduced to little more than a tenth by the end of the decade. Most of the increase went to early stage financing - less than $6 \%$ at the beginning of the decade - that increased its share of gross investments by a factor of five. It is therefore fair to conclude that venture capital finance has emerged in Germany only in the middle of the 1990s.

For the purpose of our study, we wish to concentrate on venture capital finance and analyse the valuation methodologies that are used for young, start-up companies. These are the companies where we expect traditional valuation methodologies to be most seriously challenged. Hence, in our survey we only target companies that engage in early stage financing and ignore those that are specialized on management buyouts and expansion financing.

Insert Table 2 about here

The upper panel of Table 2 shows the total venture capital invested for selected European countries. It clearly indicates that developments in Germany not only mirror similar developments in other countries but that German venture capital has caught up in importance relatively to other industrialized nations. In 1989, German venture capitalists invested less than those in Italy and the Netherlands. In 1998 and 1999, they came second only to the much larger venture capital industry in the UK in absolute terms. However, relative to the size of its economy, German venture capital is still less important than in the UK, the Netherlands, Sweden, or Belgium as the lower panel of Table 2 demonstrates.

\section{The Dataset}

\subsection{Research Methodology}

The empirical basis of our study are the completed questionnaires of 53 German venture capitalists. We contacted 95 venture capital companies that are (1) organized in the German Venture Capital Association (BVK) and (2) engaged in early stage and seed financing according to the BVK directory 2000. The questionnaire was in German. An English translation can be found in Appendix A to this paper. As the questionnaire is rather detailed and asks a number of technical questions, we felt that 
returns by mail were not practical. Therefore, we completed the questionnaires by conducting interviews over the telephone. This had two advantages. First, it increased the response rate substantially. With a response rate of $56 \%$ our telephone survey was remarkably successful and compares favourably with surveys returned by mail that typically have response rates below $30 \%$. The second advantage of a telephone survey is that we made sure that our telephone partners were experts in valuation for their companies. A survey returned by mail would not give us any control over who filled in the questionnaire. We therefore believe that our telephone survey is more accurate than surveys based on responses returned by mail.

We completed our survey in two stages, the first between the $20^{\text {th }}$ February and the $17^{\text {th }}$ March, 2001, and the second between the $6^{\text {th }}$ and the $21^{\text {st }}$ July 2001. In the first stage 40 venture capitalists participated in the survey. In the second stage another 13 companies completed the questionnaire. During our telephone interviews we found that some valuation experts we contacted were reluctant to answer questions 3 and 4 of our questionnaire. They did not wish to pass on detailed information about their valuation methodologies to outsiders and frequently referred to "internal procedures" they would not wish to comment on.

Insert Table 3 about here.

In order to check whether the sample we generated is representative of the population of German venture capitalists in 2001 we compare our sample to a larger sample of venture capitalists in Table 3. The larger sample consists of 126 venture capitalists which are BVK members and provided these data for the annual BVK report. It covers $55 \%$ of all venture capitalists and $74 \%$ of the membership of the BVK. We observe that the moments of the two distributions are quite similar. Although the companies in our sample are somewhat smaller (by $22 \%$ on average) than the companies in the larger sample, we conclude that our sample is by and large representative of the population of German venture capital companies in 2001.

The questionnaire itself was developed in two stages. In the first stage we conducted a pilot study and interviewed a number of industry experts about the questions that interest us. Here we learned in particular that our original list of valuation methodologies was too narrow. The practitioners repeatedly referred to non-standard 
methodologies or to procedures that we would not regard as valuation methodologies at all. We felt that excluding these might bias our sample and our results, so we include them.

During the interviews, we did not give our respondents any indication about the future use of the questionnaires except that it would be a scientific study that had some interest in the valuation methodologies used by venture capitalists in Germany. All questions were asked as open questions, i.e., the respondents did not know the list of potential answers on the questionnaire. The answers were ticked by the interviewer in the course of the interview. Hence, the type and ordering of the potential answers on the questionnaire could not influence the respondents. We also did not give indications about how we evaluate their responses or insinuate that there was something like a correct answer. However, in our subjective evaluation, we noticed that frequently respondents felt obliged to name valuation methods (especially DCF and real options) that they had recently learned about or felt compelled to regard as important. We did not ask any follow-up questions except those that are listed on the questionnaire. We also assured our respondents of anonymity.

\subsection{The Questionnaire}

In this section we comment on the questions in the order they appear on the questionnaire. We give a brief explanation of each question. This corresponds to the explanations we gave to respondents when they asked for clarification. We also provide some further comments and additional background as to why a particular question was included. However, this information was not made available to our respondents. Some concepts are specific to the German context and captured only approximately by our English translations. Therefore, we also provide the German terms in parentheses. An English translation of the complete questionnaire can be found in Appendix A.

Question 1: Which Valuation Methodologies Do You Use? This question forms the core of our study. We wanted to find out which valuation methodologies different venture capitalists use. The respondents could name multiple methodologies. 
- Discounted Cash Flows. DCF determines the value of a company by discounting the free expected future cash flows of a company. The discount factor is determined from a model based on capital markets theory that includes an estimate of the risk premium.

- Valuation of Profits ("Ertragswertmethode"). This method is a forerunner of the discounted cash flow methodology and is also based on free cash flows. However, the discount factor is not based on some kind of asset pricing model but formed subjectively from the perspective of the investor. This method is still widely used in Germany and taught in business schools, especially accounting departments. It is therefore also used by many CPAs.

- Book Values ("Substanzwertmethode"). This method looks at the book values and sometimes also the replacement values of all assets owned by the company in isolation. This method was taught at some German accounting departments well into the second half of the 1980s.

- Internal Rate of Return. The internal rate of return (IRR) does not fully qualify as a valuation methodology. However, some respondents referred to it.

- Economic Value Added (EVA). This methodology was originally developed as a performance measure for executive compensation. First, the capital invested in the company is determined. In a second step, the profits the company is expected to make in excess of its cost of capital are estimated. The present value of these expected "EVAs" is then added to the capital invested. This model can be considered as a version of the residual income approach.

- Multipliers and Financial Ratios. The most important financial ratios are value/sales, value/EBIT, and price/earnings. Many venture capitalists also use nonconventional multipliers, for example value/customer or value/employees. These ratios are collected for comparable, publicly listed companies. The company value is then inferred assuming that the company's respective ratio is equal to the average ratio of the comparable companies.

- Real Options. The real options approach applies an option valuation model, analyzing the whole company as a financial option. 
- Ex-Post Valuation. This is one of the methodologies that does not properly constitute a valuation method. However, it was frequently cited. Here the venture capitalist negotiates a staged financing plan with the company. If certain milestones are reached at agreed points in time, the venture capitalist makes the required payments or converts loans into an equity participation. Hence, there is an implicit valuation in the negotiated exchange of venture capital contributions for the company's equity. However, this valuation is never made explicit.

- Discounted Exit Price (also called Venture Capital Method). This is a method which is specific to the venture capital industry. It is based on the price at which the venture capitalist plans to exit and liquidate its investments. This value is typically determined either by discounting cash flows or by using multipliers. The exit price is then discounted in order to obtain a present value. The main difference between this method and Discounted Cash Flows or Valuation of Profits is the choice of the discount factor. The Venture Capital Method uses discount factors between $30 \%$ and $70 \%$ (see Sahlman, 1990) that are much higher than the costs of capital used by the DCF method (typically below 20\%). The 'theoretical' justification for these high discount factors are the high risk of the investment, its low liquidity, compensation for management services by the venture capitalist, and the bias in financial projections made by the entrepreneurs (see Sahlman, 1990). Note that the textbook approach to coping with the projection bias and the compensation for the venture capitalist's services is to include them in the numerator by adjusting the cash-flows accordingly. From the point of view of standard finance theory, the discounted exit price method, where the entrepreneur picks the numerator first and the financier picks the denominator afterwards, is clearly an ad-hoc method.

- Technology Evaluation. This method is another example of a quasi-method that does not explicitly determine the value of the company. Rather, the amount necessary to provide seed financing for a particular product is determined first. Then the investment manager of the venture capitalist will evaluate the technology with respect to criteria such as novelty of the product and barriers to entry in the market for the product. Technological implementability is also assessed. If the venture capitalist is satisfied, seed financing is granted, otherwise not. No explicit valuation is given. 
- Valuation of Financing Requirements. The venture capitalist evaluates implementability and also the quality of management. The amount of financing is determined according to the financing requirements of the project. No explicit valuation is given.

- Experience. Our study focuses on early stage financing where the application of discounted cash flows and other quantifiable, textbook methodologies is particularly problematic. Therefore many of our respondents also referred to subjective and not quantifiable factors for evaluating companies in the early stage phase. We summarize these subjective factors as "experience."

\section{Question 2: Do You Use the Data Directly from the Company's Business Plan?}

This question asks if venture capitalists base their analysis directly on forecasts made by the company, or if they depend on their own forecasts and analysis. If the answer was 'yes' we proceeded directly to question 3. If the answer was 'no,' we also asked how the venture capitalist arrives at an independent assessment. The choices are then:

- Conduct an internal study.

- Conduct an internal study with the cooperation of the company, where the company effectively provides a revised business plan under the supervision of the venture capitalist.

- Use a certified public accountant (CPA).

- Use a 'specialist,' for example an outside consultant or academic.

Question 3: How do you use DCF? Our third question asks more specific details about the implementation of DCF. It was only asked if the respondent had named DCF in question 1. In order to find out how venture capitalists implement the discounted cash flow method, we asked how they determine the discount rate, the risk premium, and the company's exposure to systematic risk. We also wanted to know for how many years they make detailed cash flow forecasts and how they calculate terminal values.

Question 4: How do you use Multipliers? Question 4 proceeds similarly and asks more detailed questions about the implementation of the multiplier method. In particular, we wanted to know which multipliers are used and according to which criteria venture capitalists select comparables. 
Question 5: What is Your Investment Horizon When You Invest in New Companies? With this question we wanted to find out whether our respondents intend their investments to be short-term or if they intend to have a long-term commitment to their portfolio companies.

Question 6: What is the Maximum Deviation You will Allow Between the Result of Your Valuation and the Value You Finally Negotiate with Your Portfolio Companies? We wanted to know how seriously venture capitalists actually take their valuations. Inevitably, the valuation is part of a negotiation process between the company and the providers of venture capital finance. We asked for the maximum value, because we assume that this is the price venture capital companies truly believe in.

Question 7: Which Fraction of Your Investments Have to be Written Off by More than 50\%? This question is critical because it leads to our measure of success of a venture capital investment. While the reach of this question is somewhat limited, it still has the advantage that it can be communicated relatively easily. We wanted to know about the "living dead" and calculate some kind of expanded insolvency rate that includes those investments with a large write-off.

Question 8: Would You Consider Outsourcing Valuation for Your Venture Capital Company? Our last question is supposed to evaluate to what extent venture capitalists regard valuation as one of their "core competencies."

\section{Descriptive Results: Valuation Methodologies used by Venture Capitalists}

In this section we provide some descriptive results about our dataset. We investigate which valuation methodologies venture capitalists that provide early stage financing use in practice and how some of the more complex valuation methodologies are applied. Table 4 presents the results to questions 1, 3 and 4 of our survey.

Insert Table 4 about here

Note that our respondents were allowed to name as many valuation methodologies as they wished. Our 53 respondents use 2.92 valuation methods on average, and only 
$15 \%$ of them rely on only one method exclusively. Therefore, most venture capitalists seem to triangulate on the correct value by using several methodologies. The most popular valuation methods are discounted cash flow techniques and multipliers. $68 \%$ of our respondents referred to at least one of the techniques described by finance textbooks, namely discounted cash flows, the economic value added method, or the valuation of profits method, which differs from DCF only through the determination of the discount rate. Multipliers also enjoy frequent usage, and most venture capitalists rely on conventional multiples like P/E-ratios, value/sales or value/EBITratios. Other multiples, like value per customer or value per employee were rarely mentioned. The real options approach is also hardly ever used.

Wide-spread use of DCF and related techniques suggests a high degree of awareness of textbook valuation methods among venture capitalists. However, we can make two further observations that contradict this impression. Firstly, only few of our respondents seem to use DCF in a way that relates discount rates to the cost of capital, as is revealed by some follow-up questions (question 3) on how they determine the discount rate. Only 10 of the 31 respondents who claimed to be using discounted cash flow techniques replied that they use either the Capital Asset Pricing Model or a Weighted Average Cost of Capital concept. Another 19 responded that they use an ad hoc interest rate chosen by the venture capitalist "internally." We further asked how they choose the risk-free rate and the risk premium. Only three out of our 31 respondents who use DCF gave answers that correspond to the suggestions of conventional finance textbooks. Clearly, CAPM or WACC are not the only way to estimate the costs of capital. However, they provide a simple framework in which the applicant can derive the opportunity costs of her investment in an objectifiable and replicable way. Alternative aproaches, e. g. those based on factor models, typically generate similar results. Note that none of these methods for calculating opportunity costs of capital would generate discount rates in the $30 \%-70 \%$ range that are often employed by venture capitalists. Hence, our follow-up question on the discount rate is aimed at distinguishing between venture capitalists that use a measure of opportunity costs of capital and those that choose ad-hoc discount factors far above any reasonable estimate of opportunity costs. If we felt that the respondent uses true opportunity costs, we counted the reply as CAPM (or WACC if this method was mentioned), because the CAPM is the starting point for all textbook methods for determining the 
discount rate. We therefore conclude that, while many venture capitalists claim to use DCF, only a minority of them implement it according to textbook prescriptions and the majority applies ad-hoc modifications. Given these subjective adjustments, the distinction between DCF and non-standard methods, especially discounted exit price, is blurred.

Our second observation is that subjective criteria and non-standard methods are still widely used. For example, $42 \%$ of our respondents mentioned techniques (ex-post valuation, technology evaluation, valuation of financial requirements) that avoid an explicit valuation. These methods have in common that the valuation by the venture capitalist is only implicit in the financing provided relative to the equity given up by the company. Also, $34 \%$ of our respondents openly said that experience and subjective factors were an important variable in their assessment. Hence, in many cases venture capitalists assess the quality of management, the quality and technological feasibility of the product, barriers to entry to the product market and other qualitative criteria. Then they determine whether the business plan has a sufficient likelihood of succeeding in light of their own experience and then make a financing decision on this basis.

Manigart et al (2000) establish with their survey that DCF is the most popular method in the Netherlands and Belgium whereas US and UK venture capitalists prefer multiples and French venture capitalists use 'relationship based' valuation methods. Our results therefore suggest that the valuation practice in Germany is more similar to that in the Netherlands and Belgium than to the US, the UK or France. Note, however, that our survey targeted only venture capitalists that are engaged in early-stage financing, whereas the sample of Manigart et al (2000) contains a more heterogeneous group of venture capitalists.

Next, we want to establish how venture capitalists combine different methodologies to arrive at a final assessment of their portfolio companies. In particular, we want to know if subjective assessments were generally used to complement the results of objectifiable methods, or if there are two groups of venture capitalists, one that prefers standard textbook methods, whereas the other avoids the use of objectifiable methodologies altogether. For this purpose, we calculate the correlations between the use of different methodologies in Table 5. 
Insert Table 5 about here.

In order to differentiate between objectifiable methods and subjective criteria, we create a new variable (which we call DCF-O, "O" for "objectifiable" in the tables) that refers to all users of DCF who use a standard method to determine the discount rate related to a measure of cost of capital. DCF-S ("S" for "subjective") refers to the complement of venture capitalists who appear to use DCF, but with a subjective or "internal" method for calculating the discount rate. In addition, we divide the valuation methods in two groups. The first group contains the objectifiable valuation methods (DCF-O, VP, IRR, EVA, MULT, RO) and the second group the subjective methods (EPV, DEP, TE, VFR, EXP). ${ }^{5} 32 \%$ of our respondents use objectifiable methods but no subjective methods. Conversely, 9\% of our respondents use only subjective methods. If we also count DCF-S as a subjective method, $15 \%$ of our respondents use only objectifiable methods and $19 \%$ only subjective methods. In Table 5, we can observe that almost all positive and statistically significant correlations are in the two outlined diagonal blocks of the table. This implies that all those who use discounted cash flow techniques according to textbook prescriptions or use some other objectifiable method were more likely to use also some of the other objectifiable methods in addition. Similarly, those who use subjective methodologies and experience as their main guide to valuation also name other subjective criteria. Table 6 corroborates this result for the objectifiable valuation methods. It displays that $50 \%$ of all respondents who use the internal rate of return (IRR) method also use DCF with a discount rate related to cost of capital. However, only $9.8 \%$ of the respondents who do not use IRR do so. This difference is highly significant. Similarly, users of multiples or real options are significantly more likely to apply DCF with a discount rate based on cost of capital than other venture capitalists. Table 6 also demonstrates that there is no association between the use of IRR, multiples or real options and the general use of DCF, regardless of how discount rates are determined.

Insert Table 6 about here.

Note that the correlation between DCF-S and the subjective valuation methods displayed in Table 5 are all negative. This implies that those who use DCF with a 
subjective assessment of the discount rate are significantly less likely to use one of the other subjective criteria. Especially, the magnitude of the correlations with 'experience' stands out: While the textbook use of DCF seems to be unrelated to the use of experience, those who use DCF with subjective adjustments tend to never refer to experience as a separate source of valuation information. Our interpretation is that those who use a number of subjective corrections and adjustments when applying the discounted cash flow technique either do not require or are not aware of the extent to which they use additional subjective assessments.

We can therefore summarize our results as follows. While discounted cash flow techniques enjoy wide-spread usage among venture capitalists, only few of them apply the method rigorously. Those venture capitalists who use DCF-O are more likely to also use other objectifiable methods like financial ratios, real options and internal rate of return in order to triangulate over alternative values to arrive at a final valuation. In contrast, venture capitalists who use one subjective criterion are prone to applying other subjective criteria and to avoiding the use of objectifiable methods altogether.

Question 2 asks whether venture capitalists use the numbers provided in the business plan by the company that seeks financing or if they try to establish their own estimates. 50 of our respondents answered that they do not use the original numbers. Instead, 46 of them carry out their own internal study. 13 respondents use certified public accountants (CPAs) and 14 say that they employ other specialists for this task. Interestingly, larger venture capitalists and venture capitalists with larger project sizes employ CPAs significantly more often than smaller funds.

We also tried to obtain sample valuations from our respondents. Although we promised utmost confidentiality, by far the most companies declined our request. Therefore, we could only obtain two sample valuations which we want to describe briefly now. The first valuation was done by one of the larger venture capitalists in our sample. Here, the cash-flow projections of the entrepreneur were judged as overly optimistic and replaced by estimates of the venture capitalist for the coming four years. The projected earnings in year 4 were multiplied by 10 in order to arrive at an

\footnotetext{
${ }^{5}$ See the text above table 5 for an explanation of the acronyms used to designate variables.
} 
estimate for the terminal value in year 4. Terminal value and projected earnings were then discounted with the discount rate $65 \%$. This discount rate was not justified in any way as an opportunity cost of this investment. The resulting value estimate was of minor importance for the financing decision. The venture capitalist based its decision mainly on the technology and management evaluation, as well as on 'experience.'

The second valuation we could obtain stems from a much smaller venture capitalist who started with a plausibility check of projected sales growth rates by comparing them with past growth rates of similar American companies. Then three valuation methods were applied: valuation of profits and two variants of the discounted exit price. The main weight was put on the discounted exit price method assuming an IPO in four years. For this, the firm multiplied projected sales in four years with a value/sales multiple that was obtained from averaging over eight comparable companies which recently listed their shares on 'Neuer Markt.' The resulting exit price was discounted with a rate of $75 \%$. This rate was determined by deducting a number of discounts from the base rate of $150 \%$. For example, the rate was reduced by 10 percentage points because the management team was judged to have sufficient technological skills. The second variant of the discounted exit price predicted potential exit prices for three types of exit: IPO, tradesale, and total loss. These three terminal payoffs were weighted with the historical frequencies provided by the BVK. The expected exit price was discounted with the 'required net return' of $25 \%$. For the valuation of profits analysis, sales and return on sales were forecasted for nine years. After that, stable earnings without growth were assumed. The resulting earnings were discounted with a rate of $35 \%$ which was not justified in any way. Due to their responses to our questionaire, both venture capitalists have been rated 'DCF-S.' in our empirical analysis

\section{Valuation Methods and Investment Success}

Our next task is to understand to what extent the approach to valuation has an impact on the performance of the venture capitalists in our sample. Does the application of textbook methods make venture capitalists more successful? Venture capitalists who have a higher ability to discriminate between good and poor investments should be expected to have a higher return on their portfolio ex-post. Unfortunately, we cannot 
measure these returns, because we neither have data on the venture capitalists' market value in our sample (only five of them are publically listed), nor do we have data on the value of their portfolio. However, even if we had additional information we would have a methodological problem as the return distribution of venture capital investments is highly skewed. A small number of highly successful investments typically compensates for a large number of failures. We approach this problem by using two measures of success that relate to the tails of the distribution of investment returns. The first is the write-off rate which measures the ex post errors venture capitalists make in their investment decisions. The second variable relates to initial public offerings undertaken by a venture capitalist (see also Gompers and Lerner, 1998).

\subsection{Valuation and Write-off Rate}

Our first measure for success is based on question 7 of our questionnaire. This question asks about the fraction of investments that have to be written off by more than 50\%. Hence, we ask about those investments where the venture capitalist realized a mistake ex-post. We did not ask directly for the complete write-offs as this number is typically small, especially for very young funds. Instead, we asked for those decisions where there was clear evidence ex-post that the investment had failed.

We acknowledge the limitations of this self-reported performance measure. The main disadvantage of using the write-off rate as a performance measure is that a higher proportion of investments that need to be written off could also reflect a higher inclination to take risk ex-ante. We would expect venture capitalists that specialize in the financing of smaller companies and companies that are in the very early stages of their development to take larger risks. They should then also experience write-offs on a larger fraction of their investments. If these venture capitalists would be rewarded through larger successes of their well performing companies, then our method would underestimate their performance. We attempt to take care of this problem by controlling for risk in the remainder of this subsection and by also looking at the upper tail of the distribution in the following subsection.

As risky investments should be more pervasive in the financing of very small companies in the earliest stage of their development, in particular in seed financing, 
we presume that write-offs are highly correlated with the size of the venture investment itself. We have three different measures of size in our data base, namely the volume invested by the fund, the number of investments by the fund, and the volume per investment undertaken by the fund (which is the ratio of the other two measures). The correlations between these measures and the write-off rate are displayed in Table 7.

Insert table 7 about here.

We expect that all size measures are negatively correlated with the write-off rate. First, the volume invested and the number of investments are measures of the size of the fund and probably also of the professionalism of the fund. We expect that larger funds invest in the later stages of the company as they have more resources to engage in the larger sized investments this requires. This is confirmed by the sign of these correlations. However, both correlations are statistically indistinguishable from zero. The measure that should be most closely related to the risk of the investment is the volume per investment, as this should be lower in the risky early stages of the venture capital investment cycle. We find that this coefficient has a $p$-value of .6 and is therefore statistically not distinguishable from zero; it also has the wrong sign, indicating that the write-off rate increases with the volume per investment in the fund. We therefore conclude that the size of the fund and the size of its average investment is not related to the failure rate of the fund. We therefore feel that our interpretation of the write-off rate as a performance measure is justified, as it does not seem to pick up the fact that funds which take higher risks by investing in smaller companies necessarily have larger write-off rates.

Insert table 8 about here.

Table 8 presents univariate regressions of the write-off rate on the use of certain valuation methodologies. First, observe that the use of discounted cash flow techniques is unrelated to success as measured by the write-off rate. However, using DCF-O results in an economically and statistically significant decline in the write-off rate: On average, the write-off rate is reduced by 5.4 percentage points. The use of multipliers and financial ratios is also negatively related to the write-off rate, although these correlations are not statistically significant in most cases. The only multiple that 
explains some of the variation in the write-off rate is the use of the Value/EBIT ratio. This result is somewhat problematic, because this ratio can only be applied to companies that have positive earnings. This would invariably be the case for larger and more mature companies which already report positive operating cash flows. Typically, for companies in an earlier stage of their development, we would have to use the Value/Sales ratio or even one of the other indicators like value per customer. As we would expect the failure rate to be larger for companies that have no positive earnings, we interpret our results on the use of multiples as inconclusive. Table 8 also shows that the use of economic value added (EVA) as a valuation method leads to a significant decline in performance. Note, however, that only two respondents reported the use of EVA (see Table 4), so that this result might well be due to a single outlier. We conclude that the use of subjective valuation criteria or the use of DCF with subjective adjustments does not lead to economically or statistically significant changes in the write-off rate. The same is true for the use of multipliers and financial ratios. However, the use of DCF-O leads to an economically and statistically meaningful reduction in incorrect investment decisions.

Question 5 of our survey investigates the time horizon for the venture capital funds in our sample. Here, most respondents did not specify a period but rather a range of periods like ' 3 to 5 years.' From these answers we calculate the upper bound of the investment horizon and construct three dummy variables that indicate whether the upper bound of the investment horizon includes or exceeds 4,5 or 6 years, respectively. Table 9 displays univariate regression results of the write-off rate on each of these dummy variables.

Insert table 9 about here.

We find that the write-off rate is negatively related to the length of the investment horizon. For the four year-horizon this result is significant at the 5\% level, and for the five year-horizon it is significant at the $10 \%$ level. A venture capitalist with an investment horizon that includes or exceeds 4 years experiences a write-off rate that is 7.5 percentage points lower on average. Investment horizons that are six years and longer also contribute to a reduction in the failure rate, but this result is no longer statistically significant. We therefore find that investors with a stronger focus on 
fundamental values and a longer-term investment horizon experience lower write-off rates.

In the remaining part of this section, we consider multiple regressions of the write-off rate that allow us to investigate to what extent our results are subject to omitted variable bias.

\section{Insert table 10 about here.}

The upper panel (models 1 to 6) of Table 10 shows regression results of the write-off rate on the use of DCF-O and six further dependent variables. This panel shows that DCF-O remains statistically significant at the $5 \%$ level except if the number of methods, the use of the EBIT multiple or the 'horizon $\geq 4$ ' dummy are included in the regression. The significance level of DCF-O only drops below $10 \%$ if the number of methods is included. The reason is that DCF-O and the number of methods are correlated: Respondents who apply DCF-O use a total of 4.4 different methods on average, whereas the other respondents only use 2.6 methods on average. Note that in Model 3 the p-value of the number of methods $(0.33)$ is markedly higher than the pvalue of DCF-O (0.19), in this sense DCF-O has more explanatory power than the number of methods. This view is also corroborated by the univariate regressions in Table 8: the number of methods can only explain $6.5 \%$ of the variation in the writeoff rate compared to $8 \%$ for DCF-O. Moreover, DCF-O is positively correlated with the use of the enterprise value/EBIT ratio, which explains the lower significance of DCF-O in Model 2.

Note that all respondents who use DCF with a discount rate based on opportunity costs also report a long investment horizon. Panel B (models 7 and 8) shows that the 'horizon $\geq 4$ ' dummy can be regarded as an alternative indicator of DCF-O: The cross-effect of DCF and this dummy is significantly different from zero. Model 8 indicates that the use of DCF in combination with a short investment horizon (smaller or equal to three years) leads to an average increase in the write-off rate by 13 percentage points. In Panel C (models 9 to 12), we finally search for the specification which explains most of the variation in the write-off rate. We establish that four variables can explain $34 \%$ of the variation in the write-off rate: the use of EVA, the total number of methods used, the use of DCF and the product of DCF use and the 
'horizon $\geq 4$ ' dummy. As argued above, the last two variables together can be considered as an alternative definition of DCF-O. Although significant, we do not comment on the EVA dummy because there are only two respondents who named EVA as a valuation method they use.

\subsection{Valuation and IPO Success}

In this subsection, we look at the number of successful venture capital investments, i.e. the other tail of the return distribution. In order to do this, we collect data on all IPOs at Germany's "Neuer Markt" that were backed by the venture capitalists in our sample. Between January 1997 and December 2001, there were 435 IPOs at "Neuer Markt" and 57 of these were backed by one of the venture capitalists in our sample. However, only 14 of the 53 venture capitalists in our sample were engaged in at least one IPO. Tables 11 and 12 show some descriptive statistics about the 57 IPOs under consideration. On average, the companies that are sold in the IPO are nine years old. The venture capitalist who backed the IPO invested in the company for the first time only a little more than two years before the IPO on average. A plausible explanation for this short period of venture capital financing is that venture capitalists specialize. One group of small venture capitalists engages in seed or early stage financing. If the start-up survives this stage, these venture capitalists cooperate with larger venture capitalists who specialize on IPOs or even sell their investments to them. Hence, only a small number of venture capitalists backs IPOs and these IPOs follow quickly after their first investment. Hence, given that our study focuses on venture capitalists engaged in early stage financing, we consider variables related to IPOs to be a somewhat problematic measure of investment success and caution the reader when interpreting the results.

Insert tables 11 and 12 about here.

The second panel of Table 11 shows that the average IPO raised 62.5 million euro, 3.9 million of which accrue to the venture capitalist. The venture capitalist retains a large stake in the company, and, in a few cases, even increases this stake. Under the assumption that this stake is sold after the lock-up period of 180 days at the prevailing market price, the total value (which includes the revenues at the time of the IPO) of the venture capitalist amounts to 28.9 million euro on average. Table 12 shows a 
break-down of the 57 IPOs by industry. The most frequent industries are biotechnology and internet followed by software, telecommunications and services. Four of the 57 IPOs were delisted by August 2002.

Based on these data we construct two variables to measure investment success. First, we use the ratio of the number of IPOs the venture capitalist was involved in to the total number of investments by this venture capitalist. Second, we calculate the ratio of the total value of all IPOs the venture capitalist was involved in and the total volume invested by the venture capitalist. As shown in Table 11, we calculate the total value as the sum of IPO revenues and hypothetical revenues if the remaining stake in the company had been sold 180 days later. Table 13 describes the distribution of these two variables across venture capitalists and displays their correlation with our size variables and the write-off rate. It turns out that both measures are significantly correlated with the size of the venture capitalists, lending support to our hypothesis that a few large venture capitalists specialize in IPOs. Remember that our first measure of investment failure, the write-off rate, is not significantly correlated with any of the three size variables. The measure based on the number of IPOs is virtually uncorrelated with the write-off rate, but the measure based on the IPO revenues is negatively - albeit not significantly - correlated with the write-off rate. A negative correlation is what we expect if our measures do not proxy for risk. If a higher writeoff rate is merely due to higher risk, then the same venture capitalist should also experience more successes. In that case, the write-off rate and IPO success should be positively correlated. Table 13 shows that this is not the case, corroborating our earlier finding that the write-off rate does not proxy for risk.

Insert table 13 and 14 about here.

Table 14 contains results of regressions of these two measures on the total volume invested, DCF-O, and on the number of methods used (across all 53 venture capitalists in our sample). As expected from the high correlations shown in Table 13, the total volume invested has strong explanatory power for both measures of IPO success. The coefficients on the other two variables have the expected sign but are clearly insignificant. Tobit regressions or Poisson regressions (not reported) yield similar signs and levels of significance. We attribute these insignificant results to the small number of venture capitalists that engage in IPOs in our sample. 


\section{Conclusions}

We conducted a survey among German venture capital funds who engage in early stage financing. Our analysis is based on a questionnaire on which we received a very high response. We not only investigate the alternative methodologies used, but also ask how they are implemented. We find that investment attitude and valuation methodologies have a statistically and economically meaningful impact on the investment performance of venture capitalists in our sample. We measure investment failure by self-reported write-off rates and investment success by the relative number of successful IPOs or the proportion of investments recouped in the course of successful IPOs. In particular, companies which not only claim to use DCF but also provide some evidence that they subject themselves to the discipline imposed by this approach have a significantly lower incidence of failed investments. In addition, the use of several different valuation methods significantly lowers the failure rate. Investment attitude also has an impact. Venture capitalists with a more speculative attitude to venture financing, i.e., those who expect to invest for less than four years in their portfolio companies, experience higher failure rates on average relative to those who take a longer term view.

Still, there is an important caveat to our analysis. It might be the case that those venture capitalists which rely on DCF as their main method of valuation are more likely to invest in more stable ventures which are further advanced in their life cycle. This lower risk will show up in fewer failures but also fewer successes. We address this question in our analysis and show that the failure rate is not correlated with those variables in our dataset that possibly proxy for risk. We also present weak evidence that the two measures are not positively correlated, which would be the case if they merely proxied for risk.

We conclude that those venture capital funds who base their investment strategy on fundamental values and a long-term view seem to have a measurable advantage over those who engage in subjective short-term trading strategies. 


\section{Appendix A: The Questionnaire}

Name of the venture capitalist company:

Volume invested:

Number of investments:

1. Which valuation methodologies do you use?

\begin{tabular}{|l|l|}
\hline DCF (Discounted Cash Flows) & \\
\hline Valuation of Profits ('Ertragswertmethode') & \\
\hline Book Values ('Substanzwertmethode') & \\
\hline IRR (Internal Rate of Return) & \\
\hline EVA (Economic Value Added) & \\
\hline Multipliers and Financial Ratios & \\
\hline Real Options & \\
\hline Ex-Post Valuation & \\
\hline Discounted Exit Price & \\
\hline Technology Evaluation & \\
\hline Valuation of Financing Requirements & \\
\hline Experience & \\
\hline Other & \\
\hline
\end{tabular}

2. Do you use the data directly from the company's business plan?

a)

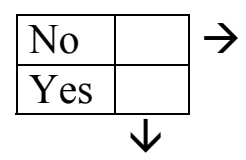

b)

\begin{tabular}{|l|l|}
\hline Internal study & \\
\hline$\ldots$ with cooperation of company & \\
\hline External accountant & \\
\hline Specialist & \\
\hline
\end{tabular}

\section{Additional questions on DCF}

a) How do you determine the discount factor?

\begin{tabular}{|l|l|}
\hline CAPM (Capital Asset Pricing Model) & \\
\hline WACC (Weighted Average Cost of Capital) & \\
\hline APV (Adjusted Present Value) & \\
\hline Internal Method & \\
\hline Other & \\
\hline
\end{tabular}

b) How do you determine the expected market return?

\begin{tabular}{|l|l|}
\hline DAX return (German top 30 stock index) & \\
\hline NEMAX return (Neuer Markt stock index) & \\
\hline Nasdaq Return & \\
\hline MSCI-Return & \\
\hline Other & \\
\hline
\end{tabular}


c) Over which horizon do you calculate the market return?

\begin{tabular}{|l|l|}
\hline 5 years & \\
\hline 10 years & \\
\hline Since the index exists & \\
\hline
\end{tabular}

d) What is the horizon for which you do an explicit valuation?

\begin{tabular}{|l|l|}
\hline 1 to 3 years & \\
\hline 4 to 5 years & \\
\hline 6 to 7 years & \\
\hline $8+$ years & \\
\hline dependent on business plan & \\
\hline
\end{tabular}

e) How do you determine the Beta of the investment?

Using a peer group

Using the industry beta

Using a VC-specific (internal) beta

Other

f) How do you determine the terminal value?

\begin{tabular}{|l|l|}
\hline with the value driver method & \\
\hline assuming perpetual growth & \\
\hline with EBITDA multiple & \\
\hline other & \\
\hline
\end{tabular}

\section{Additional questions on multiples}

a) Which multiples do you use?

\begin{tabular}{|l|l|}
\hline price/earnings ratio & \\
\hline company value/sales & \\
\hline company value/EBIT & \\
\hline company value/EBITDA & \\
\hline company value/free cash flows & \\
\hline other & \\
\hline
\end{tabular}

b) How do you determine the peer group?

\begin{tabular}{|l|l|}
\hline by industry & \\
\hline by risk structure & \\
\hline by stage of company development & \\
\hline by type of financing & \\
\hline other & \\
\hline
\end{tabular}

5. What is your investment horizon when you invest in new companies?

\begin{tabular}{|l|l|}
\hline 1 year & \\
\hline 2 years & \\
\hline 3 years & \\
\hline 4 years & \\
\hline 5 years & \\
\hline more than 5 years & \\
\hline
\end{tabular}


6. What is the maximum deviation you will allow between the result of your valuation and the value you finally negotiate with your portfolio companies?

\begin{tabular}{|l|l|}
\hline $0 \%$ to $9 \%$ & \\
\hline $10 \%$ to $19 \%$ & \\
\hline $20 \%$ to $29 \%$ & \\
\hline $30 \%$ to $39 \%$ & \\
\hline $40 \%$ to $49 \%$ & \\
\hline $50 \%$ to $59 \%$ & \\
\hline $60 \%$ to $69 \%$ & \\
\hline $70 \%$ to $79 \%$ & \\
\hline $80 \%$ to $89 \%$ & \\
\hline $90 \%$ to $99 \%$ & \\
\hline $100 \%$ and $m o r e$ & \\
\hline
\end{tabular}

7. Which fraction of your investments have to be written off by more than $\mathbf{5 0 \%}$ ?

\begin{tabular}{|l|l|}
\hline $0 \%$ to $9 \%$ & \\
\hline $10 \%$ to $19 \%$ & \\
\hline $20 \%$ to $29 \%$ & \\
\hline $30 \%$ to $39 \%$ & \\
\hline $40 \%$ to $49 \%$ & \\
\hline $50 \%$ to $59 \%$ & \\
\hline $60 \%$ to $69 \%$ & \\
\hline $70 \%$ to $79 \%$ & \\
\hline $80 \%$ to $89 \%$ & \\
\hline $90 \%$ to $100 \%$ & \\
\hline
\end{tabular}

8. Would you consider outsourcing valuation for your venture capital company? \begin{tabular}{|l|l|}
\hline No & \\
\hline Yes & \\
\hline
\end{tabular} 


\section{Appendix B: Tables}

\section{Table 1: Breakdown of Gross Investment by Stage of Company Development}

The table shows the breakdown of gross investment of all BVK (German Venture Capital Association) members from 1990 to 1999. 'Expansion' refers to the financing of new production capacities, product diversification or market expansion for firms which record profits or exceed the break-even point. 'MBO/MBI' is the financing of a management takeover, either by the current (MBO) or by an outside (MBI) management team. 'Early Stage' includes seed financing (development of an idea into marketable products) and start-up financing (for recently established firms which have so far sold little or no products). Bridge financing helps firms to improve their equity position in order to prepare for an initial public offering. Turnaround financing is intended to help firms in difficulties to improve their profitability. Source: BVK-Statistik 1990 to 1994, BVK-Jahrbuch 1996 to 2000

\begin{tabular}{|c|c|c|c|c|c|c|c|c|c|c|}
\hline & 1990 & 1991 & 1992 & 1993 & 1994 & 1995 & 1996 & 1997 & 1998 & 1999 \\
\hline Expansion & $67.20 \%$ & $66.86 \%$ & $44.57 \%$ & $60.30 \%$ & $64.79 \%$ & $53.72 \%$ & $54.62 \%$ & $47.00 \%$ & $30.26 \%$ & $35.37 \%$ \\
\hline MBO/MBI & $22.06 \%$ & $13.32 \%$ & $23.95 \%$ & $20.52 \%$ & $17.57 \%$ & $20.28 \%$ & $21.78 \%$ & $17.85 \%$ & $18.98 \%$ & $10.31 \%$ \\
\hline Early Stage & $5.81 \%$ & $5.73 \%$ & $6.79 \%$ & $8.73 \%$ & $7.37 \%$ & $13.70 \%$ & $14.23 \%$ & $15.69 \%$ & $24.93 \%$ & $32.66 \%$ \\
\hline Bridge & $3.07 \%$ & $1.26 \%$ & $11.71 \%$ & $2.61 \%$ & $5.28 \%$ & $4.69 \%$ & $1.95 \%$ & $17.22 \%$ & $12.07 \%$ & $13.72 \%$ \\
\hline Turnaround & $1.86 \%$ & $0.96 \%$ & $1.06 \%$ & $0.72 \%$ & $2.71 \%$ & $5.94 \%$ & $6.30 \%$ & $1.47 \%$ & $2.59 \%$ & $0.40 \%$ \\
\hline Other & $0.00 \%$ & $11.87 \%$ & $11.92 \%$ & $7.11 \%$ & $2.28 \%$ & $1.67 \%$ & $1.12 \%$ & $0.77 \%$ & $5.70 \%$ & $7.54 \%$ \\
\hline
\end{tabular}


Table 2: Venture Capital Financing in Europe

The upper panel shows the total venture capital invested in million $€$ for selected European countries from 1989 to 1999. Source: BVK-Jahrbuch 2000. The bottom panel displays the total venture capital invested as a percentage of GDP.

\begin{tabular}{|c|c|c|c|c|c|c|c|c|c|c|c|c|}
\hline & & 1989 & 1990 & 1991 & 1992 & 1993 & 1994 & 1995 & 1996 & 1997 & 1998 & 1999 \\
\hline \multirow{8}{*}{ 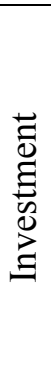 } & Germany & 527 & 1,583 & 2,193 & 2,683 & 3,054 & 3,444 & 3,997 & 3,472 & 3,941 & 5,572 & 7,896 \\
\hline & Great Britain & 6,689 & 6,729 & 8,188 & 8,621 & 8,418 & 9,337 & 9,777 & 11,194 & 14,900 & 20,008 & 28,043 \\
\hline & France & 2,137 & 2,657 & 3,114 & 3,673 & 4,022 & 4,333 & 4,736 & 4,784 & 4,968 & 4,845 & 5,279 \\
\hline & Netherlands & 898 & 993 & 1,151 & 1,204 & 1,283 & 1,427 & 1,712 & 1,986 & 2,238 & 3,313 & 4,571 \\
\hline & Italy & 691 & 841 & 1,224 & 1,516 & 1,410 & 1,454 & 1,383 & 1,385 & 1,813 & 2,417 & 3,618 \\
\hline & Sweden & 133 & 384 & 443 & 452 & 403 & 573 & 565 & 951 & 1,136 & 1,197 & 1,796 \\
\hline & Belgium & 504 & 550 & 635 & 719 & 751 & 830 & 910 & 919 & 1,037 & 965 & 1,493 \\
\hline & Europe & 12,474 & 14,825 & 18,374 & 20,373 & 20,857 & 23,120 & 25,108 & 27,085 & 32,782 & 41,850 & 58,349 \\
\hline \multirow{8}{*}{ 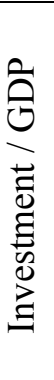 } & Germany & $0.05 \%$ & $0.14 \%$ & $0.15 \%$ & $0.18 \%$ & $0.18 \%$ & $0.20 \%$ & $0.21 \%$ & $0.18 \%$ & $0.21 \%$ & $0.29 \%$ & $0.40 \%$ \\
\hline & Great Britain & $0.88 \%$ & $0.86 \%$ & $0.98 \%$ & $1.05 \%$ & $1.03 \%$ & $1.07 \%$ & $1.13 \%$ & $1.20 \%$ & $1.28 \%$ & $1.59 \%$ & $2.07 \%$ \\
\hline & France & $0.24 \%$ & $0.28 \%$ & $0.32 \%$ & $0.35 \%$ & $0.37 \%$ & $0.38 \%$ & $0.40 \%$ & $0.39 \%$ & $0.40 \%$ & $0.37 \%$ & $0.39 \%$ \\
\hline & Netherlands & $0.42 \%$ & $0.43 \%$ & $0.47 \%$ & $0.46 \%$ & $0.46 \%$ & $0.48 \%$ & $0.54 \%$ & $0.61 \%$ & $0.67 \%$ & $0.95 \%$ & $1.24 \%$ \\
\hline & Italy & $0.09 \%$ & $0.10 \%$ & $0.13 \%$ & $0.16 \%$ & $0.17 \%$ & $0.17 \%$ & $0.16 \%$ & $0.14 \%$ & $0.18 \%$ & $0.23 \%$ & $0.33 \%$ \\
\hline & Sweden & $0.07 \%$ & $0.20 \%$ & $0.23 \%$ & $0.23 \%$ & $0.25 \%$ & $0.33 \%$ & $0.31 \%$ & $0.46 \%$ & $0.54 \%$ & $0.56 \%$ & $0.80 \%$ \\
\hline & Belgium & $0.35 \%$ & $0.35 \%$ & $0.39 \%$ & $0.41 \%$ & $0.41 \%$ & $0.42 \%$ & $0.43 \%$ & $0.43 \%$ & $0.48 \%$ & $0.43 \%$ & $0.64 \%$ \\
\hline & Europe & $0.27 \%$ & $0.31 \%$ & $0.32 \%$ & $0.34 \%$ & $0.35 \%$ & $0.37 \%$ & $0.38 \%$ & $0.39 \%$ & $0.45 \%$ & $0.55 \%$ & $0.73 \%$ \\
\hline
\end{tabular}




\section{Table 3: Representativeness of Our Sample}

The table shows summary statistics for the distribution of the volume invested by each venture capitalist. All numbers (except skewness) are in million $€$. The left column describes the sample of 53 venture capitalists that completed our survey. The right column describes a sample of 126 BVKregistered companies that provided information on their invested capital to the BVK. Source: BVK Directory 2000.

\begin{tabular}{lcc}
\hline & $\begin{array}{c}\text { Sample of 53 venture } \\
\text { capitalists who } \\
\text { completed the survey }\end{array}$ & $\begin{array}{c}\text { Sample of 126 venture } \\
\text { capitalists organized in } \\
\text { BVK }\end{array}$ \\
\hline mean & 42.8 & 54.7 \\
median & 15.5 & 20.8 \\
maximum & 400.0 & 566.7 \\
minimum & 1.2 & 0.2 \\
standard deviation & 73.2 & 89.1 \\
skewness & 3.1 & 3.2 \\
\hline
\end{tabular}

\section{Table 4: Use of Valuation Methodologies}

The table provides the absolute and relative frequencies with which the different valuation methods have been named in our survey. If a respondent mentioned the discounted cash flow method (DCF) in question 1 and stated in the follow-up question 3 that he or she uses the CAPM or WACC method for calculating the discount rate, we counted the answer as 'DCF with objectifiable discount rate.' If the respondent in addition uses the DAX, Nasdaq, S\&P500 or the MSCI for measuring the market premium and a peer group or industry group to estimate the company's beta, we counted the answer as 'DCF with consistent follow-up answers.'

\begin{tabular}{lcc}
\hline Method & Absolute Frequency Relative Frequency \\
\hline Discounted cash flows & 31 & $58 \%$ \\
$\quad$ with objectifiable discount rate & 10 & $19 \%$ \\
$\quad$ with consistent follow-up answers & 3 & $6 \%$ \\
Valuation of profits & 14 & $26 \%$ \\
Book values & 1 & $2 \%$ \\
Internal rate of return & 12 & $23 \%$ \\
Economic value added & 2 & $4 \%$ \\
Multipliers and financial ratios & 32 & $60 \%$ \\
$\quad$ price/earnings ratio & 17 & $32 \%$ \\
$\quad$ enterprise value/sales ratio & 23 & $43 \%$ \\
enterprise value/EBIT ratio & 16 & $30 \%$ \\
$\quad$ enterprise value/EBITDA ratio & 4 & $8 \%$ \\
$\quad$ enterprise value/free cash flows & 3 & $6 \%$ \\
other & 6 & $11 \%$ \\
Real options & 6 & $11 \%$ \\
Ex-post valuation & 14 & $26 \%$ \\
Discounted exit price & 9 & $17 \%$ \\
Technology evaluation & 6 & $11 \%$ \\
Valuation of financing requirements & 10 & $19 \%$ \\
Experience & 18 & $34 \%$ \\
\hline Total number of responses & 53 & $100 \%$ \\
\hline
\end{tabular}


Table 5: Use of Valuation Methodologies: Correlations

The table contains correlations between the respective methods above the diagonal. Below the diagonal the corresponding p-values for the two-sided t-test for zero correlation is shown. Cells with correlations that are significantly different from zero at the 5\% significance level are shaded. DCF-S refers to answers which give DCF but neither use the CAPM nor the WACC method for the calculation of the discount rate. DCF-O refers to answers which include DCF and usage of the CAPM or the WACC method.

\begin{tabular}{|c|c|c|c|c|c|c|c|c|c|c|c|c|c|}
\hline & DCF & DCF-S & CF-O & VP & IRR & EVA & MULT & RO & EPV & DEP & TE & VFR & EXP \\
\hline Discounted cash flows (DCF) & +++ & +++ & +++ & $7.0 \%$ & $9.0 \%$ & $16.7 \%$ & $2.2 \%$ & $-6.2 \%$ & $-27.7 \%$ & $-12.9 \%$ & $-6.2 \%$ & $-27.9 \%$ & $-44.7 \%$ \\
\hline with subjective discount rate (DCF-S) & +++ & +++ & +++ & $4.0 \%$ & $-25.4 \%$ & $4.2 \%$ & $-21.1 \%$ & $-28.9 \%$ & $-31.0^{c}$ & $-26.4 \%$ & $-4.6 \%$ & $-29.2 \%$ & $-41,8 \%$ \\
\hline with objectifiable discount rate (DCF-O) & +++ & +++ & +++ & $3.9 \%$ & $43.0 \%$ & $15.8 \%$ & $29.2 \%$ & $28.4 \%$ & $3.9 \%$ & $16.7 \%$ & $-2.0 \%$ & $1.4 \%$ & $-4,0 \%$ \\
\hline Valuation of profits (VP) & 0.616 & 0.778 & 0.780 & +++ & $18.7 \%$ & $33.1 \%$ & $-12.7 \%$ & $-7.9 \%$ & $2.9 \%$ & $-15.7 \%$ & $-7.9 \%$ & $-18.0 \%$ & $-15.9 \%$ \\
\hline Internal rate of return (IRR) & 0.523 & 0.067 & 0.001 & 0.180 & +++ & $36.6 \%$ & $7.0 \%$ & $9.1 \%$ & $8.5 \%$ & $-12.5 \%$ & $-10.0 \%$ & $-3.0 \%$ & $-10.2 \%$ \\
\hline (EVA) & 0.233 & 0.765 & 0.260 & 0.016 & 0.007 & +++ & $16.0 \%$ & $-7.1 \%$ & $10.6 \%$ & $-9.0 \%$ & $-7.1 \%$ & $-9.6 \%$ & $-14.2 \%$ \\
\hline inancial ratios (MULT) & 0.875 & 0.129 & 0.034 & 0.364 & 0.621 & 0.251 & +++ & $-19.8 \%$ & $13.5 \%$ & $5.8 \%$ & $16.8 \%$ & $19.3 \%$ & $1.1 \%$ \\
\hline Ex-post & 0.045 & 0.024 & 0.780 & 0.835 & 0.546 & 0.450 & 0.334 & 0.017 & +++ & $7.1 \%$ & $-7.9 \%$ & $14.9 \%$ & $38.4 \%$ \\
\hline ce (DEP) & 0.358 & 0.057 & 0.231 & 0.262 & 0.374 & 0.524 & 0.679 & 0.266 & 0.614 & +++ & $-0.3 \%$ & $3.9 \%$ & $31.2 \%$ \\
\hline Technology evaluation (TE) & 0.661 & 0.744 & 0.886 & 0.574 & 0.516 & 0.615 & 0.230 & 0.362 & 0.574 & 0.983 & +++ & $43.7 \%$ & $-0.5 \%$ \\
\hline of financial requirements (VFR) & 0.043 & 0.034 & 0.921 & 0.198 & 0.829 & 0.496 & 0.165 & 0.886 & 0.288 & 0.783 & 0.001 & +++ & $6.1 \%$ \\
\hline Experience (EXP) & 0.008 & 0.002 & 0.774 & 0.257 & 0.466 & 0.310 & 0.939 & 0.075 & 0.005 & 0.023 & 0.973 & 0.662 & +++ \\
\hline
\end{tabular}




\section{Table 6: Contingencies among Objectifiable Valuation Methods}

The table displays contingencies between DCF (usage of the discounted cash flow method), DCF-O (DCF with WACC or CAPM) and the use of other objectifiable valuation methods. To give an example how to read the table, consider the first data line. It shows that 12 respondents said that they use IRR. $66.7 \%$ of these also use DCF and 50\% DCF-O. In addition, the table displays the p-value of Fisher's exact test of the null hypothesis of no association.

\begin{tabular}{lrrr}
\hline & obs. & DCF & \multicolumn{1}{c}{ DCF-O } \\
\hline Internal rate of returns (IRR) & & & \\
$\quad$ mentioned & 12 & $66.7 \%$ & $50.0 \%$ \\
$\quad$ not mentioned & 41 & $56.1 \%$ & $9.8 \%$ \\
$\quad$ p-value of Fisher's exact test & & 0.7404 & 0.0053 \\
\hline $\begin{array}{l}\text { Multipliers and financial ratios (MULT) } \\
\text { mentioned }\end{array}$ & 32 & $59.4 \%$ & $28.1 \%$ \\
$\quad$ not mentioned & 21 & $57.1 \%$ & $4.8 \%$ \\
$\quad$ p-value of Fisher's exact test & & 1.0000 & 0.0688 \\
\hline Real options (RO) & 6 & $50.0 \%$ & $50.0 \%$ \\
$\quad$ mentioned & 47 & $59.6 \%$ & $14.9 \%$ \\
$\quad$ not mentioned & & 0.6834 & 0.0732 \\
$\quad$ p-value of Fisher's exact test & & \\
Objectifiable methods (other than DCF) & 28 & $55.3 \%$ & $26.3 \%$ \\
$\quad$ IRR, MULT, RO or EVA mentioned & 15 & $66.7 \%$ & $0.0 \%$ \\
none of these mentioned & & 0.5441 & 0.0462 \\
$\quad$ p-value of Fisher's exact test & & & \\
\hline
\end{tabular}

\section{Table 7: Performance and Size}

The table displays the correlation between three measures of size and the write-off rate (mid-point of the ticked interval, measured in percentage points) as well as the p-value of the two-sided t-test for zero correlation. In addition the table provides the mean of the three size measures.

\begin{tabular}{lccc}
\hline \multicolumn{1}{c}{ Size measure } & Mean & Correlation & p-value \\
\hline Number of investments & 20.7 & $-6.6 \%$ & 0.638 \\
Total volume invested $€ 39.75$ million & $-11.6 \%$ & 0.406 \\
Volume per investment $€ 2.23$ million & $7.3 \%$ & 0.604 \\
\hline
\end{tabular}




\section{Table 8: The Effect of Valuation Methods on the Write-off Rate}

This table contains univariate regression results of the write-off rate (mid-point of the ticked interval, measured in percentage points) on an intercept and a dummy variable which indicates whether the specified method has been named by the respondent. The last row shows a regression on an intercept and the number of methods named by the respondent. In addition to the regression $\mathrm{R}^{2}$, intercept and slope estimates, the table contains the p-value of the two sided t-test for the slope estimate being zero. 'DCF with subjective discount rate' refers to answers which give DCF but neither use the CAPM nor the WACC method for the calculation of the discount rate. 'DCF with objectifiable discount rate' refers to answers which include DCF and usage of the CAPM or the WACC method. Models with slope estimate significantly different from zero at the $5 \%$ significance level are shaded.

\begin{tabular}{lcrcc}
\hline \multicolumn{1}{c}{ Independent variable } & Intercept & Slope & $\mathrm{p}$-value & $\mathrm{R}^{2}$ \\
\hline Discounted cash flows & 18.18 & 0.37 & 0.864 & 0.001 \\
$\quad$ with objectifiable discount rate & 19.42 & -5.42 & 0.041 & 0,080 \\
$\quad$ with subjective discount rate & 16.88 & 3.84 & 0.071 & 0,063 \\
Valuation of profits & 18.85 & -1.70 & 0.476 & 0.010 \\
Internal rate of return & 18.66 & -1.16 & 0.646 & 0.004 \\
Economic value added & 17.94 & 12.06 & 0.026 & 0.094 \\
Multipliers and financial ratios & 19.76 & -2.26 & 0.293 & 0.022 \\
$\quad$ price/earnings ratio & 19.44 & -3.27 & 0.145 & 0,041 \\
$\quad$ enterprise value/sales ratio & 19.67 & -2.93 & 0.166 & 0,037 \\
$\quad$ enterprise value/EBIT ratio & 19.86 & -4.86 & 0.031 & 0,089 \\
$\quad$ enterprise value/EBITDA ratio & 18.47 & -0.97 & 0.809 & 0,001 \\
enterprise value/free cash flows & 18.80 & -7.13 & 0.114 & 0,048 \\
$\quad$ other & 19.04 & -5.71 & 0.082 & 0,058 \\
Real options & 18.62 & -1.95 & 0.558 & 0.007 \\
Ex-post valuation & 18.85 & -1.70 & 0.476 & 0.010 \\
Discounted exit price & 18.86 & -2.75 & 0.326 & 0.019 \\
Technology evaluation & 18.62 & -1.95 & 0.558 & 0.007 \\
Valuation of financial requirements & 19.19 & -4.19 & 0.117 & 0.048 \\
Experience & 19.29 & -2.62 & 0.237 & 0.027 \\
Number of methods & 22.30 & -1.33 & 0.065 & 0.065 \\
\hline
\end{tabular}

\section{Table 9: Performance and Investment Horizon}

This table contains univariate regression results of the write-off rate (mid-point of the ticked interval, measured in percentage points) on an intercept and a dummy variable which indicates whether the upper limit of the investment horizon given by the respondent includes or exceeds the specified number of years (question 5). In addition to the regression $\mathrm{R}^{2}$, intercept and slope estimates, the table contains the $\mathrm{p}$-value of the two sided t-test for the slope estimate being zero.

\begin{tabular}{cccccc}
\hline $\begin{array}{l}\text { Upper boundary of } \\
\text { investment horizon } \\
\text { includes or exceeds }\end{array}$ & $\begin{array}{c}\text { Number of } \\
\text { observations }\end{array}$ & Intercept & Slope & p-value & $\mathrm{R}^{2}$ \\
\hline 4 years & 47 & 25.00 & -7.45 & 0.022 & 0.099 \\
5 years & 42 & 22.27 & -4.89 & 0.056 & 0.070 \\
6 years & 19 & 19.12 & -2.01 & 0.359 & 0.017 \\
\hline
\end{tabular}




\section{Table 10: Multiple Regression Results}

The table displays multivariate regression results of the write-off rate (mid-point of the ticked interval, measured in percentage points). Each cell contains the corresponding regression estimate and the p-value of a two-sided t-test for this estimate being zero in parenthesis. 'DCF-O' is a dummy variable that equals one if the answer includes DCF and usage of the CAPM or the WACC method. 'EVA', 'EBIT' and 'DCF' are dummy variables which equal one if the corresponding methods have been named. 'horizon $\geq$ 4 ' is a dummy variable which equals one if the upper limit of the investment horizon given by the respondent includes or exceeds 4 years. 'DCF * (horizon $\geq 4$ )' denotes the cross effect of 'DCF' and 'horizon $\geq 4$.'

\begin{tabular}{|c|c|c|c|c|c|c|c|c|c|c|c|c|}
\hline Model & Intercept & DCF-O & EVA & EBIT & $\begin{array}{l}\text { No. of } \\
\text { methods }\end{array}$ & $\begin{array}{c}\text { horizon } \\
\geq 4\end{array}$ & $\begin{array}{c}\text { Total } \\
\text { volume } \\
\text { invested }\end{array}$ & $\begin{array}{l}\text { Volume per } \\
\text { investment }\end{array}$ & $\mathrm{DCF}$ & $\begin{array}{c}\mathrm{DCF} * \\
\text { (horizon } \geq \\
4)\end{array}$ & $\mathrm{R}^{2}$ & $\begin{array}{c}\text { adjusted } \\
\mathrm{R}^{2}\end{array}$ \\
\hline 1 & $\begin{array}{c}19.09 \\
(0.000)\end{array}$ & $\begin{array}{c}-6.51 \\
(0.011)\end{array}$ & $\begin{array}{c}14.16 \\
(0.007)\end{array}$ & & & & & & & & 0.206 & 0.174 \\
\hline 2 & $\begin{array}{c}20.46 \\
(0.000)\end{array}$ & $\begin{array}{c}-4.42 \\
(0.092)\end{array}$ & & $\begin{array}{c}-4.08 \\
(0.069)\end{array}$ & & & & & & & 0.139 & 0.105 \\
\hline 3 & $\begin{array}{c}21.49 \\
(0.000)\end{array}$ & $\begin{array}{c}-3.96 \\
(0.188)\end{array}$ & & & $\begin{array}{c}-0.80 \\
(0.325)\end{array}$ & & & & & & 0.098 & 0.061 \\
\hline 4 & $\begin{array}{c}25.00 \\
(0.000)\end{array}$ & $\begin{array}{c}-4.51 \\
(0.081)\end{array}$ & & & & $\begin{array}{c}-6.49 \\
(0.044)\end{array}$ & & & & & 0.152 & 0.119 \\
\hline 5 & $\begin{array}{c}19.85 \\
(0.000)\end{array}$ & $\begin{array}{c}-5.33 \\
(0.045)\end{array}$ & & & & & $\begin{array}{c}-0.011 \\
(0.445)\end{array}$ & & & & 0.091 & 0.054 \\
\hline 6 & $\begin{array}{c}19.18 \\
(0.000) \\
\end{array}$ & $\begin{array}{c}-5.37 \\
(0.044)\end{array}$ & & & & & & $\begin{array}{c}0.101 \\
(0.654)\end{array}$ & & & 0.083 & 0.047 \\
\hline 7 & $\begin{array}{c}24.67 \\
(0.000)\end{array}$ & & & & & $\begin{array}{c}-7.51 \\
(0.022)\end{array}$ & & & $\begin{array}{c}0.66 \\
(0.747)\end{array}$ & & 0.101 & 0.065 \\
\hline 8 & $\begin{array}{c}18.33 \\
(0.000)\end{array}$ & & & & & $\begin{array}{c}-0.18 \\
(0.968)\end{array}$ & & & $\begin{array}{c}13.33 \\
(0.024)\end{array}$ & $\begin{array}{l}-14.35 \\
(0.023)\end{array}$ & 0.192 & 0.142 \\
\hline 9 & $\begin{array}{c}22.57 \\
(0.000)\end{array}$ & $\begin{array}{c}-2.55 \\
(0.405)\end{array}$ & $\begin{array}{c}11.76 \\
(0.042)\end{array}$ & $\begin{array}{c}-1.98 \\
(0.355)\end{array}$ & $\begin{array}{c}-1.41 \\
(0.085)\end{array}$ & $\begin{array}{c}0.15 \\
(0.971)\end{array}$ & & & $\begin{array}{c}9.41 \\
(0.103)\end{array}$ & $\begin{array}{c}-9.56 \\
(0.119)\end{array}$ & 0.359 & 0.259 \\
\hline 10 & $\begin{array}{c}22.70 \\
(0.000)\end{array}$ & $\begin{array}{c}-2.55 \\
(0.400)\end{array}$ & $\begin{array}{c}11.77 \\
(0.040)\end{array}$ & $\begin{array}{c}-1.97 \\
(0.345)\end{array}$ & $\begin{array}{c}-1.41 \\
(0.080)\end{array}$ & & & & $\begin{array}{c}9.28 \\
(0.039)\end{array}$ & $\begin{array}{c}-9.41 \\
(0.037)\end{array}$ & 0.359 & 0.276 \\
\hline 11 & $\begin{array}{c}23.62 \\
(0.000)\end{array}$ & & $\begin{array}{c}11.71 \\
(0.040)\end{array}$ & $\begin{array}{c}-2.07 \\
(0.319)\end{array}$ & $\begin{array}{c}-1.73 \\
(0.016)\end{array}$ & & & & $\begin{array}{c}9.33 \\
(0.037)\end{array}$ & $\begin{array}{l}-10.30 \\
(0.019)\end{array}$ & 0.349 & 0.280 \\
\hline 12 & $\begin{array}{c}23.63 \\
(0.000)\end{array}$ & & $\begin{array}{c}12.79 \\
(0.023)\end{array}$ & & $\begin{array}{c}-1.93 \\
(0.005)\end{array}$ & & & & $\begin{array}{c}9.57 \\
(0.032)\end{array}$ & $\begin{array}{l}-10.72 \\
(0.015)\end{array}$ & 0.335 & 0.280 \\
\hline
\end{tabular}




\section{Table 11: Description of the IPO Sample}

This table contains mean, median, minimum and maximum of a number of variables of the IPO sample. The 'time between first investment and IPO' is the difference between the calendar year of the IPO and the calendar year in which the venture capitalist invested in this company for the first time. The 'IPO revenues of the VC' is the number of shares sold (bought) by the venture capitalist in the IPO multiplied by the issue price. The 'total IPO value to the VC' is the IPO revenue of the VC plus the hypothetical revenue from selling the remaining stake in the company at the prevailing market price 180 days after the IPO.

\begin{tabular}{lcccc}
\hline & Mean & Median & Minimum & Maximum \\
\hline Age of the IPO company (years) & 9.16 & \multicolumn{1}{c}{7} & 1 & \multicolumn{1}{c}{7} \\
Time between first investment and IPO (years) & 2.37 & \multicolumn{1}{c}{2} & \multicolumn{1}{c}{0} & \multicolumn{1}{c}{7} \\
\hline Total revenue from IPO (in million euro) & 62.45 & 47.60 & 13.80 & 276.20 \\
IPO revenue of the VC (in million euro) & 3.89 & 1.94 & -11.56 & 26.99 \\
Total IPO value to the VC (in million euro) & 28.94 & 14.19 & 0.22 & 203.52 \\
\hline Block held by venture capitalist & & & & \\
$\quad$ before the IPO & $13.50 \%$ & $12.40 \%$ & $0.45 \%$ & $37.63 \%$ \\
$\quad$ after the IPO & $7.94 \%$ & $7.15 \%$ & $0.00 \%$ & $24.25 \%$ \\
\hline
\end{tabular}

Table 12: Break-down of the 57 IPO companies by industry

\begin{tabular}{lc}
\hline & Number \\
\hline technology and engineering & 5 \\
medical technology and health care & 5 \\
biotechnology & 12 \\
telecommunication & 6 \\
computer equipment & 2 \\
software & 7 \\
internet & 12 \\
services & 6 \\
media and entertainment & 1 \\
\hline
\end{tabular}




\section{Table 13: Description of the Measures of IPO Success}

The table displays mean, median, minimum and maximum and some correlations of the two measures of investment success. 'Number of IPOs' is the number of IPOs, which have been backed by a given venture capitalist, divided by the number of investments of this venture capitalist. 'IPO value' is the sum of the 'Total IPO value to the VC' (see Table 11) for all IPOs, which have been backed by a given venture capitalist, divided by the total volume invested by this venture capitalist. The numbers in parentheses are $\mathrm{p}$-values of the two-sided t-test for zero correlation.

\begin{tabular}{lcr}
\hline & Number of IPOs & IPO value \\
\hline Mean & $3.66 \%$ & $21.37 \%$ \\
Median & $0.00 \%$ & $0.00 \%$ \\
Minimum & $0.00 \%$ & $0.00 \%$ \\
Maximum & $33.33 \%$ & $285.22 \%$ \\
\hline Correlation with number of investments & $14.10 \%(0.3140)$ & $29.63 \%(0.0348)$ \\
Correlation with total volume invested & $33.62 \%(0.0138)$ & $47.38 \%(0.0004)$ \\
Correlation with volume per investment & $8.66 \%(0.5376)$ & $7.48 \%(0.6018)$ \\
Correlation with the write-off rate & $2.18 \%(0.8767)$ & $-14.26 \%(0.3181)$ \\
\hline
\end{tabular}

\section{Table 14: The Effect of Valuation Methods on the IPO Success}

The table displays multivariate regression results of two IPO success measures. Each cell contains the corresponding regression estimate and the p-value of the two-sided t-test for this estimate being zero in parenthesis. 'Number of IPOs' is the number of IPOs, which have been backed by a given venture capitalist, divided by the number of investments of this venture capitalist. 'IPO value' is the sum of the 'Total IPO value to the VC' (described in Table 11) for all IPOs, which have been backed by a given venture capitalist, divided by the total volume invested by this venture capitalist. 'DCF-O' is a dummy variable that equals one if the answer includes DCF and usage of the CAPM or the WACC method.

\begin{tabular}{|c|c|c|c|c|c|}
\hline $\begin{array}{l}\text { Independent } \\
\text { variable }\end{array}$ & Intercept & $\begin{array}{l}\text { Total volume } \\
\text { invested }\end{array}$ & DCF-O & $\begin{array}{c}\text { No. of } \\
\text { methods }\end{array}$ & adjusted $\mathrm{R}^{2}$ \\
\hline number of IPOs & $\begin{array}{c}0.92 \% \\
(0.4108)\end{array}$ & $\begin{array}{c}0.04 \% \\
(0.0013)\end{array}$ & $\begin{array}{l}1.47 \% \\
(0.5145)\end{array}$ & & 0.1697 \\
\hline number of IPOs & $\begin{array}{c}-0.21 \% \\
(0.9174) \\
\end{array}$ & $\begin{array}{c}0.04 \% \\
(0.0069) \\
\end{array}$ & & $\begin{array}{c}0.55 \% \\
(0.4298) \\
\end{array}$ & 0.1732 \\
\hline IPO value & $\begin{array}{c}2.69 \% \\
(0.7614)\end{array}$ & $\begin{array}{c}0.38 \% \\
(0.0005)\end{array}$ & $\begin{array}{l}16.77 \% \\
(0.3494)\end{array}$ & & 0.2069 \\
\hline IPO value & $\begin{array}{l}-4.03 \% \\
(0.8064) \\
\end{array}$ & $\begin{array}{c}0.35 \% \\
(0.0029) \\
\end{array}$ & & $\begin{array}{c}3.87 \% \\
(0.4889) \\
\end{array}$ & 0.2003 \\
\hline
\end{tabular}




\section{References}

Alford, A., 1992, The effect of the set of comparable firms on the accuracy of the price-earnings valuation method, Journal of Accounting Research 30, 3-30.

Benninga, Simon and Sarig, Oded, 1997, Corporate Finance - A Valuation Approach, New York u. a.: McGraw-Hill.

Boatsman, J. and E. Baskin, 1981, Asset valuation with incomplete markets, The Accounting Review 56, 38-53.

Brav, Alon and Paul A. Gompers, 1997, Myth or reality? The long-run underperformance of initial public offerings: Evidence from venture and nonventure capital-backed companies, The Journal of Finance 52, 1791-1821.

Brealey, Richard A. and Stewart C. Myers, 2000, Principles of Corporate Finance, Irwin/McGraw-Hill, New York.

Bruner, R.F., K.M. Eades, R. Harris and R.C. Higgins, 1998, Best practices in estimating the cost of capital: survey and synthesis, Financial Practice and Education $8,13-28$.

Copeland, Tom, Tim Koller and Jack Murrin, 1990, Valuation: Measuring and Managing the Value of Companies, John Wiley \& Sons, New York.

Cornell, Bradford, 1993, Corporate Valuation: Tools for Effective Appraisal and Decision Making, McGraw-Hill, New York.

Damodaran, Aswath, 2001, The Dark Side of Valuation: Valuing Old Tech, New Tech, and New Economy Companies, Prentice Hall, Upper Saddle River.

Drukarczyk, Jochen, 2001, Unternehmensbewertung, Verlag Vahlen, Munich.

Epps, Rupert W. and Cheryl E. Mitchem, 1994, A comparison of capital budgeting techniques with those used in Japan and Korea, Advances in International Accounting 7, 205-214.

Gilson, S.C., E.S. Hotchkiss and R.S. Ruback, 2000, Valuation of bankrupt firms, Review of Financial Studies 13, 43-74.

Gitman, Lawrence J. and Vincent A. Mercurio, 1982, Cost of capital techniques used by major U.S. firms: survey and analysis of Fortune's 1000, Financial Management 14, 21-29.

Gompers, Paul A. and Josh Lerner, 1998, The determinants of corporate venture capital success: Organizational structure, incentives, and complementarities, NBER working paper.

Gompers, Paul A. and Josh Lerner, 1999, The Venture Capital Cycle, MIT Press, Cambridge. 
Graham, John R. and Campbell R. Harvey, 2001, The theory and practice of corporate finance: evidence from the field, Journal of Financial Economics 60, 187-243.

Kaplan, Steven N. and Richard S. Ruback, 1995, The valuation of cash flow forecasts: An empirical analysis, The Journal of Finance 50, 1059-1093.

Kim, Moonchul and Jay R. Ritter, 1999, Valuing IPOs, Journal of Financial Economics 53, 409-437.

Leopold, Günter and Holger Frommann, 1998, Eigenkapital für den Mittelstand, Beck Verlag, Munich

Manigart, Sophie, Koen De Waele, Mike Wright, Ken Robbie, Philippe Desbrières, Harry Sapienza and Amy Beekman, 2000, Venture capitalists, investment appraisal and accounting information: comparative study of the USA, UK, France, Belgium and Holland, European Financial Management 6, 389-403.

Manigart, Sophie, Mike Wright, Ken Robbie, Philippe Desbrières and Koen De Waele, 1997, Venture capitalists' appraisal of investment projects: An empirical European study, Entrepreneurship Theory and Practice 21, 29-43.

Moore, James S. and Alan K. Reichert, 1983, An analysis of the financial management techniques currently employed by large U.S. corporations, Journal of Business Finance and Accounting 10, 623-645.

Palepu, Krishna G., Victor L. Bernard and Paul M. Healy, 2000, Business Analysis and Valuation Using Financial Statements - Text and Cases, South-Western College Publishing, Cincinnati (OH).

Ross, Stephen A., Randolph W. Westerfield and Jeffrey F. Jaffe, 2001, Corporate Finance, McGraw-Hill/Irwin, New York

Sahlman, William A., 1990, The structure and governance of venture-capital organizations, Journal of Financial Economics 27, 473-521.

Sangster, Alan, 1993, Capital investment appraisal techniques: a survey of current usage, Journal of Business Finance and Accounting 20, 307-332.

Schefczyk, Michael, 2000, Finanzieren mit Venture Capital, Schäfer-Poeschel, Stuttgart.

Shao, Lawrence P. and Alan T. Shao, 1996, Risk analysis and capital budgeting techniques of U.S. multinational enterprises, Managerial Finance 22, 41-57.

Stanley, Marjorie T. and Stanley B. Block, 1984, A survey of multinational capital budgeting, The Financial Review 19, 36-54.

Stummer, Frank and Bernd Nolte, 2000, Die Entwicklung des deutschen Beteiligungskapitalmarkts, Finanz Betrieb, pp. 808-811. 